\title{
Association of Phytophthora cinnamomi with White Oak Decline in Southern Ohio
}

\author{
Annemarie M. Nagle, Department of Plant Pathology, The Ohio State University, Columbus, OH 43210; Robert P. \\ Long, United States Department of Agriculture Forest Service, Northern Research Station, Delaware, OH 43015; \\ Laurence V. Madden, Department of Plant Pathology, Ohio Agricultural Research and Development Center, Woos- \\ ter, $\mathrm{OH}$ 44691; and Pierluigi Bonello, Department of Plant Pathology, The Ohio State University, Columbus, OH \\ 43210
}

\begin{abstract}
Nagle, A. M., Long, R. P., Madden, L. V., and Bonello, P. 2010. Association of Phytophthora cinnamomi with white oak decline in southern Ohio. Plant Dis. 94:1026-1034.

A decline syndrome and widespread mortality of mature white oak tree (Quercus alba) associated with wet and low-lying areas has been recently observed in southern Ohio forests. Previous studies have isolated Phytophthora cinnamomi from white oak rhizospheres. In 2008 and 2009, $P$. cinnamomi population densities in two healthy and two declining white oak stands at Scioto Trail State Forest were quantified and potential roles of three environmental drivers of Phytophthora spp.-induced decline were assessed: soil texture, soil moisture, and topography. Significantly higher $P$. cinnamomi propagule densities were found in declining stands in both years but propagule densities were not associated with soil moisture content. Trends in population densities were not correlated with soil moisture or topographic position within field sites. There was a positive, exponential relationship between overall $P$. cinnamomi population levels and soil moisture on a seasonal scale in 2008 but not 2009. Sites with greater soil clay content were associated with greater decline. Effects of $P$. cinnamomi inoculum and periodic flooding on root health of 1-year-old potted white oak trees grown in native soil mixes in the greenhouse were examined. Root systems of potted oak were significantly damaged by soil inoculation with $P$. cinnamomi, especially under flooding conditions. Results of these studies support the hypothesis that $P$. cinnamomi is a contributing agent to white oak decline in southern Ohio.
\end{abstract}

Oak species compose nearly a quarter of total tree volume in southern Ohio forests (20). Trees in the white oak group (Leucobalanus), especially white oak (Quercus alba L.), are highly valued timber species. White oak ranks fifth in growing stock and second in total board foot volume in Ohio after yellow poplar, and produces highquality veneer logs and harder, more durable lumber than oak species in the red oak group, which cohabit these sites (35).

A pronounced lack of natural regeneration of Quercus spp., possibly in response to fire suppression, is a significant management problem in this region and continues to be investigated (14). Conversely, premature mortality of large trees has not been a historical issue. However, in the last 5 years, state forest management personnel at several southern Ohio state forests have noted widespread decline and mortality affecting mature, overstory white oak trees. With the composition of these forests already in flux due to fire suppression and the consequent increase in importance of

Corresponding author: P. Bonello

E-mail: bonello.2@osu.edu

Accepted for publication 15 April 2010.

doi:10.1094/PDIS-94-8-1026

(C) 2010 The American Phytopathological Society more fire-susceptible tree species (e.g., tulip poplar and maples), the loss of large numbers of overstory white oak trees is a critical problem, not only because of their timber value but also because of their importance as mast sources for seedling recruitment and wildlife (22).

Oak mortality in southern Ohio has not been associated primarily with pathogenic or insect factors and, therefore, is being conceptualized as a decline syndrome, or a disease of complex etiology (21). Tree declines are typically characterized by a complex interplay of site, environmental, and secondary biotic factors; therefore, declines are, by nature, difficult to study and remain poorly understood $(21,23,33)$. Elucidation of the damaging agent or agents, disease-conducive elements of the environment, and host susceptibility over time is needed to better understand this disease.

The declining white oak trees in southern Ohio forests display typical progressive dieback of the crown, browning and retention of foliage on dead branches, and death of entire trees. Sustained drought between 1999 and 2001 and an acute growing season drought in 2002, coupled with moderate to severe defoliation by a variety of forest insects (half-wing geometer [Phigalia titea Cramer], forest tent caterpillar [Malacosoma disstria Hubner], and common oak moth [Phoberia atomaris
Hubner]) were likely inciting factors. Widespread decline and mortality developed between 2003 and 2005, when the region experienced excessive precipitation. Decline was observed to occur first in groups of trees situated in bottomland areas, along drainage channels, and in ravine bottoms, progressing gradually upslope. Decline was also patchy across the landscape, suggesting a pathogenic component. Similar patterns in mortality were noted in early twentieth-century descriptions of chestnut stands affected by the root-rotting oomycete Phytophthora cinnamomi Rands in the southern United States (7), and have been observed in other Phytophthora spp.-mediated diseases of forest trees (28).

The decline was first documented and appears to be most severe at Scioto Trail State Forest, which is situated approximately $11 \mathrm{~km}$ south of Chillicothe, OH. $P$. cinnamomi was recovered from the rhizospheres of white oak trees at Scioto Trail during a wider survey of Phytophthora spp. in 10 northern U.S. states (1). Subsequent surveys recovered $P$. cinnamomi from both declining and apparently healthy stands (2). The presence of this pathogen combined with apparent association of decline with hydrological patterns and patchiness suggest that the syndrome may have a Phytophthora component; however, lack of a clear association of decline in crown vigor with Phytophthora spp. incidence (2) suggests possible interplay between the pathogen and soil or site factors. Manifestation and severity of symptoms in other Phytophthora diseases of forest trees have been shown to be highly dependent upon environmental conditions and their interactions with pathogen activity $(9,16,23,34)$.

Balci et al. (2) surveyed rhizosphere soil from healthy and declining trees at Scioto Trail and found that declining trees had fewer fine roots. P. cinnamomi population density was higher in the rhizosphere of declining than healthy trees and Phytophthora spp. were isolated more often in areas with higher integrated moisture index values $(2,15)$. Results of this and previous studies seem to indicate that population levels of $P$. cinnamomi, rather than incidence, may be more important in predicting disease occurrence. However, relationships between population levels and 
potential drivers of disease (e.g., topography and soil moisture) and the relationship between $P$. cinnamomi population levels and white oak root health have not been considered.

The overall goal of this research was to determine whether $P$. cinnamomi is a contributor to white oak decline at Scioto Trail State Forest in southern Ohio. The objectives of the field study were to investigate $P$. cinnamomi population dynamics at the site and landscape scales, and explore relationships between population densities and topography, soil moisture and texture, and site decline status. The objective of a complementary greenhouse trial was to evaluate the influence of soil inoculum concentration and artificial flooding on root health in white oak seedlings.

\section{MATERIALS AND METHODS}

Field site selection and setup. In 2006, 102 0.08-ha plots, each surrounding a central white oak, were established throughout Scioto Trail State Forest. Crowns of all oak trees within the plots were visually assessed and trees were rated based on the following scale: $1 \leq 10,2=11$ to $25,3=$ 26 to 50 , and $4>51 \%$ dieback; and $5=$ standing dead. Sites were designated as healthy if the mean rating for all oak trees in the plot was less than 2.5 and declining for mean ratings greater than 2.5. In the fall of 2007, two sites rated as healthy (Healthy 1 and 2, mean ratings 1.9 and 1.6, respectively), and two as declining (Declining 1 and 2, mean ratings 3.8 and 3.1 , respectively) were selected for inclusion in the population density study. The four sites had similar topographies and were not contiguous with one another (Healthy 1: $39^{\circ} 11^{\prime} 50.22^{\prime \prime} \mathrm{N}, 82^{\circ} 57^{\prime} 5.41^{\prime \prime} \mathrm{W}$; Healthy 2: $39^{\circ} 11^{\prime} 30.19^{\prime \prime} \mathrm{N}, 82^{\circ} 57^{\prime} 6.26^{\prime \prime}$ W; Declining 1: $39^{\circ} 13^{\prime} 51.41^{\prime \prime} \mathrm{N}, 82^{\circ} 57^{\prime}$ $1.22^{\prime \prime} \mathrm{W}$; Declining 2: $39^{\circ} 13^{\prime} 37.28^{\prime \prime} \mathrm{N}$, $\left.82^{\circ} 55^{\prime} 39.69^{\prime \prime} \mathrm{W}\right)$.

In 2007, 54 of the original 102 plots were sampled for textural analysis. Four soil samples were excavated in cardinal directions adjacent to the bole of the central white oak tree. Surface mineral soils constituting the A horizon (the upper mineral soil layer with organic matter accumulation and eluviation of iron and aluminum oxides and silicate clays; mean horizon thickness $=5.75 \mathrm{~cm}$ ) were sampled separately from $\mathrm{B}$ horizon soils, which were differentiated by both color and texture from the overlying layers. Only the upper $15 \mathrm{~cm}$ of the B horizon was collected. The four samples from each tree were composited by horizon and textures were determined separately for the A and B horizons using the hydrometer procedure (30). Briefly, air-dried soils were sieved using a 2-mm sieve, and the soil fraction passing through the sieve was used for determining texture. Percent sand and clay were determined by hydrometer reading and percent silt was estimated by subtraction. From the
54 sampled plots, healthy sites with a rating $<1.9(n=9)$ and declining sites with a rating $>3.0(n=13)$ (i.e., sites with higher and lower decline ratings relative to the four experimental sites) were selected for texture comparisons.

In spring 2008, two 120-m transects were established perpendicular to the slope contour in Healthy 1, Healthy 2, Declining 1 , and Declining 2, and seven sampling points were arranged at $20-\mathrm{m}$ intervals along each transect, with $10 \mathrm{~m}$ of separation between transects. A notable feature of the Healthy 1 site was the presence of a natural spring near the top of the transects, which made the soil in this area much wetter than comparable transect positions in other sites.

$P$. cinnamomi population levels and moisture in field soils. Once a month from July to October 2008 and from June to August 2009, one 10-cm-deep by 10 $\mathrm{cm}$-diameter soil core was collected from each sampling point in the low-, mid-, and high-elevation positions along the transects to evaluate population density of $P$. cinnamomi. Litter was scraped from atop the soil prior to sampling. Soil was transported to the laboratory in coolers with ice. Care was taken to ensure that samples did not come in contact with the ice and freeze at any point. Samples were stored in a $17^{\circ} \mathrm{C}$ incubator and processed within 2 days. Instantaneous volumetric soil moisture measurements were taken twice a month at the points of soil collection and at the four additional points along the transects. To obtain readings, a Hydrosense probe (Campbell Scientific) fitted with 10-cm prongs was fully inserted into the soil.

In the laboratory, replicate soil cores (from the two points at each elevation level) were pooled and thoroughly mixed. Population density at each elevation level was assessed using a modified version of the soil dilution plating method (9). Two 30-g (fresh weight) subsamples were each homogenized in $100 \mathrm{ml}$ of sterile ultrapure water and passed through nested 250- and $38-\mu \mathrm{m}$ sieves in order to concentrate $P$. cinnamomi chlamydospores and reduce contaminants. Matter retained in the 38- $\mu \mathrm{m}$ sieve was resuspended in a small amount of sterile ultrapure water and distributed onto the surface of five $10-\mathrm{cm}$ plates containing slightly modified PARPH-5\% cV8A Phytophthora spp.-selective medium (11) (pimaricin [Calbiochem], $0.5 \mathrm{mg} / \mathrm{liter}$; sodium ampicillin [Shelton Scientific] 250 $\mathrm{mg} / \mathrm{liter}$; rifampicin [Calbiochem] 10 $\mathrm{mg} /$ liter dissolved first in $1 \mathrm{ml}$ of dimethylsulfoxide; terraclor, $66.7 \mathrm{mg} / \mathrm{liter}$; and hymexazol, $50 \mathrm{mg} / \mathrm{liter}$, in a basal medium of unbuffered 5\% V8 agar). Plates were incubated at $17^{\circ} \mathrm{C}$ for 2 days, the slurry was rinsed from the surface of the agar, and plates were examined under a dissecting microscope for growth of $P$. cinnamomi colonies. Suspected colonies, based on hyphal and colony morphology, were marked on the plates and incubated for an additional $48 \mathrm{~h}$, after which a final colony count was made. Population densities were calculated as number of colonies per $100 \mathrm{~g}$ of dry soil. In 2008 , in order to calculate dry mass of soil sampled, we assumed that proportions of water in soil by volume and mass are equivalent $(1 \mathrm{ml}=$ $1 \mathrm{~g}$ ), and used volumetric soil moisture measurements taken in the field to standardize counts by dry mass of soil. In 2009, dry mass of 30-g (fresh weight) soil samples was calculated by air drying the samples for at least 2 weeks.

Morphological identity of $P$. cinnamomi was confirmed via polymerase chain reaction (PCR). In some cases, subculture of every colony from soil dilution plates was impossible due to high densities or contamination; however, confidence in colony counts was high based upon the distinctive morphology of the pathogen in culture. At least one representative colony from each plate with a positive morphological identity was subcultured onto PARPH-V8 for 4 to 5 days, hyphal tipped onto nonselective $5 \% \mathrm{~V} 8$ medium, and grown at $17^{\circ} \mathrm{C}$ for approximately 7 days. Hyphal material was scraped off an approximately $1-\mathrm{cm}^{2}$ portion of the agar surface, DNA was extracted using a boiling miniprep method (19), and either used immediately in PCR or stored at $-20^{\circ} \mathrm{C}$. Amplification reactions were performed in a BioRad IQ5 real-time PCR machine in a $20-\mu$ l volume with final reagent concentrations as follows: template DNA ( $2 \mu \mathrm{l}$ of extract) at 5 to $50 \mathrm{ng} / \mu \mathrm{l}, 12.5$ $\mu l$ of BioRad IQ5 SybrGreen $2 \times$ Supermix, and $0.05 \mu \mathrm{M}$ each LPV3f (5'-GTGCAG ACTGTCGATGTG-3') and LPV3r (5'GAACCACAACAGGCACGT-3') primers specific for the $L P V$ putative storage protein gene in $P$. cinnamomi (19). PCR protocols in Kong et al. (19) were modified for use on a real-time PCR system as follows: denaturation at $96^{\circ} \mathrm{C}$ for $3 \mathrm{~min} ; 40$ cycles of $94^{\circ} \mathrm{C}$ for $30 \mathrm{~s}, 60^{\circ} \mathrm{C}$ for $45 \mathrm{~s}$, and $72^{\circ} \mathrm{C}$ for $1 \mathrm{~min} ; 72^{\circ} \mathrm{C}$ for $10 \mathrm{~min}$; and 61 cycles at $65^{\circ} \mathrm{C}$ for $10 \mathrm{~s}$ for melting-point determination. Successful amplification of the 450-bp fragment and amplicon melting-point matches $\left(91.0 \pm 0.5^{\circ} \mathrm{C}\right)$ to two previously characterized $P$. cinnamomi isolates from Scioto Trail (provided by Dr. Yilmaz Balci, University of Maryland) were used to confirm isolate identity. If a PCR positive was not obtained for a plate, population counts for that plate were excluded from analyses. PCR positives were obtained for all but 4 of the 155 isolates tested.

White oak seedling propagation. White oak seedlings for use in greenhouse experiments were propagated from acorns collected at Scioto Trail in fall 2007. Viable seed were separated by floating acorns in water, and those that sank were kept in open plastic Ziploc bags in a $4^{\circ} \mathrm{C}$ cold room until planting in native soil mix in January 2008. Sprouted acorns were 
planted in 4-by-21-cm cone-tainer pots and stored in a $4^{\circ} \mathrm{C}$ cold room to maintain shoot dormancy until transfer to a heated greenhouse for emergence assessments.

Native soil was obtained from four randomly selected soil pits located throughout Healthy 1, Healthy 2, Declining 1, and Declining 2 in fall 2007. Each pit was dug to a depth of 20 to $30 \mathrm{~cm}$. Soil from pits within a site was pooled, air dried, sieved to remove large debris, and stored in covered 19-liter buckets at ambient temperature. Native soils were amended to achieve a 1:0.5:0.5 ( $\mathrm{vol} / \mathrm{vol} / \mathrm{vol})$ mixture of native soil:perlite:vermiculite to enhance porosity conducive to plant growth $(12,26)$.

Seedlings were watered as needed throughout the growing season and were grown in a greenhouse maintaining temperatures of 20 to $32^{\circ} \mathrm{C}$ with $49 \%$ average relative humidity. From mid-October 2008 to mid-February 2009, oak trees were kept in a minimum-heat greenhouse to fulfill winter dormancy requirements.

Seedling emergence assessments. Several growth parameters were recorded for white oak seedlings planted in each of the four soil types to assess possible effects of site of soil origin: percent survival, days to shoot emergence, days to leaf emergence, and height and number of leaves 2 weeks after shoot emergence. Two cohorts of acorns were observed in this manner. In a pilot study, 20 acorns were planted per soil type (total $n=80$ ) and were placed in a heated greenhouse in January 2008. After shoot emergence and leaf development, seedlings were transplanted from conetainers into custom-made, 10-by-30-cm, 2liter PVC pots with mesh screens in the bottom for drainage. A second, larger cohort (80 acorns per soil type, total $n=320$ ) were planted in cone-tainers at the same time but kept in a $4{ }^{\circ} \mathrm{C}$ cold room to maintain shoot dormancy until transfer to the greenhouse in June 2008.

Inoculum preparation. Three $P$. cinnamomi isolates recovered from Scioto Trail soil in summer 2008 were used to inoculate white oak seedlings in the greenhouse. Isolates originating from three different field plots (Healthy 1, Declining 1, and Declining 2) were collected on different dates (July, August, and September) and were maintained on 5\% V8 medium in a $17^{\circ} \mathrm{C}$ incubator until use.

A 2:1 (vol/vol) mixture of sterilized vermiculite: $10 \% \mathrm{~V} 8$ broth was prepared following published methods (27). Finegrade vermiculite was sterilized by autoclaving twice for $60 \mathrm{~min}$ on consecutive days in 4-liter Erlenmeyer flasks. V8 broth was added and the mixture was autoclaved again. A cork borer was used to remove mycelial plugs from 1-week-old pure cultures of $P$. cinnamomi and isolates were seeded into separate flasks of the cooled medium (four plugs per flask). Inoculated flasks were incubated in darkness at room temperature for 10 days with periodic shaking to encourage colonization. Vermiculite was plated on nonselective V8 prior to use to ensure purity and full colonization. Equal amounts of inoculum from each isolate were mixed for use in soil inoculations.

Seedling treatments. In May 2009, 1year-old white oak trees that had been a part of the pilot study (described above) were used to test effects of potting soil origin (healthy or declining), moisture regime, and varying inoculum densities on root health. This study had a full factorial design, with three soil inoculum density levels (including the control) and two moisture treatments. Seedlings were subjected to one of the following six treatments: (i) NF0: no flooding, $0 \%$ inoculum; (ii) F0: flooding, $0 \%$ inoculum; (iii) NF2: no flooding, 2\% inoculum; (iv) F2: flooding, 2\% inoculum; (v) NF5: no flooding, 5\% inoculum; and (vi) F5: flooding, 5\% inoculum. Two seedlings growing in each of the four soil sources were used per treatment group (total of 48 seedlings). Inoculated trees were confined in individual plastic containers to collect excess irrigation water and reduce risk of crosscontamination. Each seedling was watered every third day with $200 \mathrm{ml}$ of tap water. Trees were completely randomized in four blocks on a greenhouse bench and were maintained under the greenhouse conditions detailed above.

Oak seedlings were removed carefully from the soil in their 2-liter PVC pots. The soil was then thoroughly mixed with one of the following inoculum mixtures and the seedlings were replanted in their original pots: $0 \%$ inoculum $(100 \mathrm{ml}$ of sterile vermiculite/V8), $2 \%$ inoculum $(60 \mathrm{ml}$ of sterile vermiculite/V8 $+40 \mathrm{ml}$ of colonized vermiculite/V8 inoculum), or $5 \%$ inoculum (100 $\mathrm{ml}$ of colonized vermiculite/V8 inoculum).

Flooding treatments were performed for a period of 48 h every 2 weeks to encourage disease development. Flooding was achieved by placing the seedlings into separate 64-liter plastic bins for each inoculum level and filling the bins with tap water to the soil surface line.

Seedling response evaluation. Seedlings were destructively sampled 3 months after inoculation. Any seedlings dying prior to the harvest date were processed in the same manner as described below. Trees were removed from their pots, soil was washed from the root systems with tap water, and the roots were blotted dry with paper towels. Root systems were separated from shoots at the soil line, fine roots were removed from main roots, and tap roots were thoroughly examined for evidence of necrosis. Percentage of necrotic tap root surface area was estimated visually on the following scale: $0=$ no damage, $1=$ up to $25 \%, 2=25$ to $50 \%, 3=50$ to $75 \%$, and 4 $=75$ to $100 \%$ necrotic $(25,32)$. Three to four approximately 5-mm sections of main root tissue (including necrotic areas if present) were removed and embedded in PARPH-V8 medium to test for presence of P. cinnamomi. Root systems were oven dried at $60^{\circ} \mathrm{C}$ for a week (when reduction in mass was no longer observed) and then weighed. Root loss in inoculated root systems was estimated by comparing mean root dry mass with noninoculated root systems. Three representative pots in each of the six treatment groups were randomly selected to determine final inoculum density in the potting soil. A 10 -g soil sample from each pot was dilution plated (using the methods described above) on $1010-\mathrm{cm}$ plates of PARPH-V8, colonies were counted after $48 \mathrm{~h}$, and density counts were standardized based on soil dry weights.

Data analyses. For field survey data, analysis of variance (ANOVA; including repeated measures ANOVA for soil moisture and population density data) was used to test for effects of decline status (declining or healthy), slope position (low, mid, or high), sampling date, and interactions between these variables on soil moisture levels, soil texture components, and population density. The square-root of population density was used in the analysis to help standardize variances and provide a linear scale. Correlation analysis was used to examine associations between seasonal variation in soil moisture levels and total population density of $P$. cinnamomi throughout the summer. Analyses were conducted using either the general linear model routine in SPSS 17 for Windows (SPSS, Inc.) or the MIXED procedure in SAS (SAS, Inc.).

For seedling emergence assessments, effects of trial date and soil type (healthy or declining) on white oak seedling survival rates were analyzed using Pearson $\chi^{2}$ tests of independence in the Crosstabs function of SPSS. Multivariate ANOVA was used to examine effects of trial date, soil type, and their interaction on time to shoot and leaf emergence, seedling height, and number of leaves at 2 weeks post shoot emergence. Growth data were log transformed to satisfy assumptions of ANOVA.

There were not enough seedlings from each of the four potting soil sources (healthy 1 , healthy 2 , declining 1 , and declining 2) (two trees per treatment) to analyze effects of individual soil sources on response variables in the greenhouse study. Therefore, data from trees originally planted in the two healthy and two declining soils (four trees per treatment) were pooled for analysis of inoculum dose response data. Overall effects of block, soil source (healthy or declining), inoculum treatment, and flooding on response variables (final inoculum density, root dry mass, and necrosis score) were analyzed with ANOVA. Pairwise comparisons between treatments for each response variable were made using the least significant 
difference test. Because the original data did not meet the ANOVA assumptions, analyses were based on ranks of the data (29).

\section{RESULTS}

Texture of field soils. In the four study sites, healthy sites had lower levels of clay and higher levels of sand than declining sites, especially in the B horizon (Table 1). When the additional 50 plots for which we performed textural analyses were considered, declining sites with mean crown ratings $>3.0(n=13)$ had significantly higher clay content in the $\mathrm{B}$ horizon $\left(F_{1,21}\right.$ $=7.893, P=0.011)$ than healthy sites with mean crown ratings $<1.9(n=9)$ but did not differ in sand and silt content or $\mathrm{A}$ horizon texture.

Soil moisture and $P$. cinnamomi population trends in field soils. Effects of decline status, slope position, sampling date, and their interactions on average monthly soil moisture levels and population densities in 2008 and 2009 are summarized in Tables 2 and 3.

Soil moisture levels varied by topographic position of sampled point in both years $(P<0.03)$. Moisture was generally highest at lowest elevation points and declined at higher elevations. There was also a significant interaction of position and decline status in $2008\left(F_{2,47}=4.09, P=\right.$ 0.03 ) but not in 2009. A general decline in soil moisture levels was observed throughout the summer of 2008, with a significant effect of sampling date $\left(F_{3,47}=15.49, P<\right.$ $0.001)$. Soil moisture levels did not decline as markedly throughout the summer of 2009 but there was still a significant effect of sampling date $\left(F_{2,35}=9.37, P=0.002\right)$.

Population densities of $P$. cinnamomi varied widely by slope position within sites, between sites, and across times, and there was no clear patterning of propagules along the topographical gradients tested. However, significant effects of decline status on overall population density were found, with declining stands having average population levels nearly 4 times those of healthy stands in $2008\left(F_{1,6}=9.63, P=\right.$ 0.02 ; Fig. 1A) and 36 times in $2009\left(F_{1,21}\right.$ $=4.75, P=0.04$; Fig. 1B). A borderline significant interaction of decline status and slope position on population density was also observed in 2008 (Table 3); the interaction reflected a higher population density for the intermediate slope position in the declining stands in comparison with the other slope positions (data not shown). However, there was no difference in summer average soil moistures between healthy and declining stands in either year (Fig. 1A and B). There was borderline evidence $(P=0.06)$ that population density increased over time in 2009, and there was also a significant interaction of stand status and time $\left(F_{2,21}=4.43, P=0.03\right)$, neither of which was found in 2008 (Table 3; Fig. 2 ). The interactions reflected the fact that population density in the declining stands (but not in the healthy stands) was higher at the last sample date compared with the earlier months in 2009 (Fig. 2B).

When total monthly population densities of $P$. cinnamomi (regardless of site decline status) were considered, a significant, exponential positive correlation was found with monthly mean soil moisture levels in 2008 (Fig. 3A). There was no apparent relationship between total monthly population densities and monthly mean soil moisture levels in 2009 (Fig. 3B).

Seedling emergence assessments. Seedling survival did not vary by trial date or soil type (healthy or declining). There were no interactive effects of trial date and soil type on time to shoot or leaf emergence, seedling height, or number of leaves. Times to shoot and leaf emergence were longer in the January 2008 pilot study (average 25.8 and 31.7 days, respectively) relative to the June trial (average 9.1 and 12.4 days, respectively). The differences between the January and June trials were likely related to an abbreviated cold treatment period in the pilot study that affected shoot dormancy (10) and overall colder ambient temperatures in January. These differences in tree physiological development between the winter and spring trials were reflected in a significant effect of trial date on time to shoot emergence $\left(F_{1,278}=788.21, P<0.001\right)$ and leaf emergence $\left(F_{1,278}=1347.11, P<0.001\right)$. However, there was not a significant effect of trial date on seedling height or number of leaves. None of the seedling growth parameters tested differed significantly between soil types (data not shown).

Seedling responses to treatment. Of the 48 experimental seedlings, 1 died prior

Table 1. Textural analysis of soils in two healthy and two declining 0.08-ha experimental plots at Scioto Trail State Forest in southern Ohio for A and B soil horizons

\begin{tabular}{|c|c|c|c|c|c|c|c|}
\hline \multirow[b]{2}{*}{ Site } & \multirow[b]{2}{*}{ Rating $^{\mathbf{a}}$} & \multicolumn{2}{|c|}{ Sand $(\%)$} & \multicolumn{2}{|c|}{ Silt (\%) } & \multicolumn{2}{|c|}{ Clay (\%) } \\
\hline & & $\mathbf{A}$ & B & $\mathbf{A}$ & B & $\mathbf{A}$ & B \\
\hline Healthy 1 & 1.9 & 15.1 & 16.7 & 67.5 & 63.5 & 17.4 & 19.8 \\
\hline Healthy 2 & 1.6 & 12.6 & 13.0 & 69.1 & 67.8 & 18.3 & 19.2 \\
\hline Declining 1 & 3.8 & 7.3 & 3.8 & 64.2 & 65.8 & 28.5 & 30.4 \\
\hline Declining 2 & 3.1 & 12.9 & 5.4 & 62.5 & 67.2 & 24.6 & 27.5 \\
\hline
\end{tabular}

a Decline ratings are means of visual crown assessments of all oak trees within plots, based on the following scale: $1=\leq 10,2=11-25,3=26-50$, and $4>51 \%$ dieback; and $5=$ standing dead. Texture data were obtained from homogenized soil composites from four soil pits located at each plot center.

Table 2. Results of repeated-measures analysis of variance, detailing effects of white oak decline status, slope position, sampling date, and their interactions on average monthly soil moisture levels at Scioto Trail State Forest, southern Ohio, in summer 2008 (4 months sampled) and 2009 (3 months sampled)

\begin{tabular}{|c|c|c|c|c|c|c|}
\hline \multirow[b]{3}{*}{ Source variable } & \multicolumn{6}{|c|}{ Effects on monthly average soil moisture ${ }^{a}$} \\
\hline & \multicolumn{3}{|c|}{ July-October 2008} & \multicolumn{3}{|c|}{ June-August 2009} \\
\hline & df & $F$ & $P$ & df & $F$ & $P$ \\
\hline Decline status (S) & 1,47 & 0.00 & 0.994 & 1,35 & 0.46 & 0.507 \\
\hline Slope position $(\mathrm{P})$ & 2,47 & 4.26 & 0.026 & 2,35 & 5.18 & 0.017 \\
\hline Sampling date (D) & 3,47 & 15.49 & $<0.001$ & 2,35 & 9.37 & 0.002 \\
\hline $\mathrm{S} \times \mathrm{P}$ & 2,47 & 4.09 & $\mathbf{0 . 0 3 0}$ & 2,35 & 0.19 & 0.829 \\
\hline $\mathrm{S} \times \mathrm{D}$ & 3,47 & 0.30 & 0.826 & 2,35 & 0.04 & 0.962 \\
\hline$P \times D$ & 6,47 & 0.23 & 0.963 & 4,35 & 0.11 & 0.977 \\
\hline $\mathrm{S} \times \mathrm{P} \times \mathrm{D}$ & 6,47 & 0.50 & 0.800 & 4,35 & 0.11 & 0.978 \\
\hline
\end{tabular}

a Significant factors at $P<0.05$ are highlighted in bold.

Table 3. Results of repeated-measures analysis of variance, detailing effects of white oak decline status, slope position, sampling date, and their interactions on Phytophthora cinnamomi soil population densities at Scioto Trail State Forest, southern Ohio, in summer 2008 (4 months sampled) and 2009 (3 months sampled)

\begin{tabular}{|c|c|c|c|c|c|c|}
\hline \multirow[b]{3}{*}{ Source variable } & \multicolumn{6}{|c|}{ Effects on population density ${ }^{a}$} \\
\hline & \multicolumn{3}{|c|}{ July-October 2008} & \multicolumn{3}{|c|}{ June-August 2009} \\
\hline & df & $\boldsymbol{F}$ & $\boldsymbol{P}$ & df & $\boldsymbol{F}$ & $P$ \\
\hline Decline status (S) & 1,6 & 9.63 & 0.021 & 1,21 & 4.74 & 0.041 \\
\hline Slope position $(\mathrm{P})$ & 2,6 & 2.16 & 0.196 & 2,21 & 0.70 & 0.509 \\
\hline Sampling date (D) & 2,24 & 1.05 & 0.389 & 2,21 & 3.25 & 0.059 \\
\hline $\mathrm{S} \times \mathrm{P}$ & 3,6 & 4.25 & 0.071 & 2,21 & 0.57 & 0.573 \\
\hline $\mathrm{S} \times \mathrm{D}$ & 3,24 & 1.02 & 0.403 & 2,21 & 4.43 & 0.025 \\
\hline $\mathrm{P} \times \mathrm{D}$ & 6,24 & 1.09 & 0.394 & 4,21 & 0.42 & 0.792 \\
\hline
\end{tabular}

a Significant factors at $P<0.05$ are highlighted in bold. 
to the harvest date (treatment F0, planted in soil from Declining 1). Upon inspection, this tree had girdling collar rot and extensive fine root loss (10.84 g below control mean root dry mass), and $P$. cinnamomi was isolated from necrotic collar and root tissues. Although no other trees died, some developed foliar symptoms (color change, scorching, and loss of foliage) but there was no direct association with inoculum treatment, flooding, and root damage.

There were no significant effects of block on final inoculum density, necrosis score, or root dry mass. There was also no significant effect of potting mix soil origin (healthy or declining) on final inoculum density, necrosis score, or root dry mass. Addition of $P$. cinnamomi inoculum to native soil mixes had a significant effect on all three response variables (final inoculum density: $F_{2,18}=17.151, P=0.001$; necrosis score: $F_{2,46}=19.875, P<0.001$; root dry mass: $F_{2,47}=5.476, P=0.008$ ). Periodic flooding treatment had a significant effect on root dry mass $\left(F_{1,47}=7.584, P=\right.$ $0.009)$ and necrosis score $\left(F_{1,46}=8.842, P\right.$ $=0.005)$ but not on inoculum density. There was also an interactive effect of soil origin and flooding treatment on final inoculum density $\left(F_{1,18}=7.593, P=0.025\right)$. There were no interactive effects of soil source, inoculum dose, or flooding treatment for root dry mass or necrosis score.

Subsequent analyses were simplified to examine the combined effects of inoculum load and flooding treatment (i.e. of treatments NF0, F0, NF2, F2, NF5, and F5). There was a significant overall effect of treatment on all three response variables (tap root necrosis score: $F_{5,46}=11.301, P$ $<0.001$; root dry mass: $F_{5,46}=4.515, P=$ 0.002; final inoculum density: $F_{5,18}=$ $3.959, P=0.021$; Fig. 4 A-C).
Though flooding did not significantly increase naturally occurring inoculum densities, necrosis scores, or root loss in F0 soils (relative to NF0 soils), it did appear to raise inoculum densities and lesions above the minimum levels of detection. Mean soil inoculum density was highest in NF5 trees, and no inoculum was recovered from NF0 soils (Fig. 4A). Treatment with inoculum significantly increased final inoculum densities relative to control densities (NF0) in NF2, NF5, and F5. The highest mean tap root damage was seen in F5, and three of eight trees in this treatment had estimated tap root necrosis $>75 \%$ (score $=4)$. No other treatments had trees with tap root necrosis levels higher than $60 \%$ (score $\leq 3$ ). No lesions were observed on tap roots of NF0 (control trees; Fig. 4B). All groups treated with inoculum mixtures (both flooded and nonflooded) had significantly higher root necrosis scores than the control (Fig. 4B). Of eight trees in each treatment group, $P$. cinnamomi was reisolated from root tissues of $0 \%$ of NF0 trees, $25 \%$ of F0 trees, $50 \%$ of NF2 and NF5 trees, and $100 \%$ of F2 and F5 trees. The NF0 and F0 treatments had the highest mean root dry masses. Significant declines in root dry mass compared with the control were seen in the F2 and F5 treatments (Fig. 4C).

\section{DISCUSSION}

We sought to explore the biology and distribution of P. cinnamomi at Scioto Trail State Forest and its possible involvement in white oak decline, with surveys of population densities and environmental variables over two summers. Field surveys revealed evidence that declining stands support higher population levels than healthy stands. Thus, we conducted a complementary greenhouse study to examine effects of periodic flooding and soil inoculation with $P$. cinnamomi on root health in potted white oak seedlings.

A decline in soil moisture with elevation within field sites was observed, as anticipated. However, the significant interaction of position and decline status in 2008 indicates that moisture trends with position were different in declining and healthy stands. The interaction likely reflects the reversal of the overall trend of declining moisture with elevation observed in Healthy 1 (likely due to the hydrogeological differences described above), though this interaction was not significant in 2009.

Within field sites, population patterns were not affected by soil moisture or topography. Declining sites had significantly more $P$. cinnamomi propagules than healthy sites in both 2008 and 2009 but site types did not differ in summer average soil moisture. However, the exponential relationship observed between monthly mean soil moisture and total population density in 2008 indicates that soil moisture patterns may affect population levels on a seasonal scale. Soils in Declining 1 and Declining 2 also contained more clay and less sand than the two healthy sites. When soil textures were compared in additional sites at Scioto Trail, declining sites (those with decline ratings $>3.0$ ) had a significantly higher percentage of clay in the $\mathrm{B}$ horizon than healthy sites (decline ratings $<1.9$ ), suggesting that finer-textured soils may enhance disease development. In the greenhouse, white oak seedlings potted in soils from the two healthy and two declining sites did not differ in survival rates or any growth parameters tested. One-yearold white oak trees inoculated with $P$. cinnamomi showed higher levels of root ne-
A

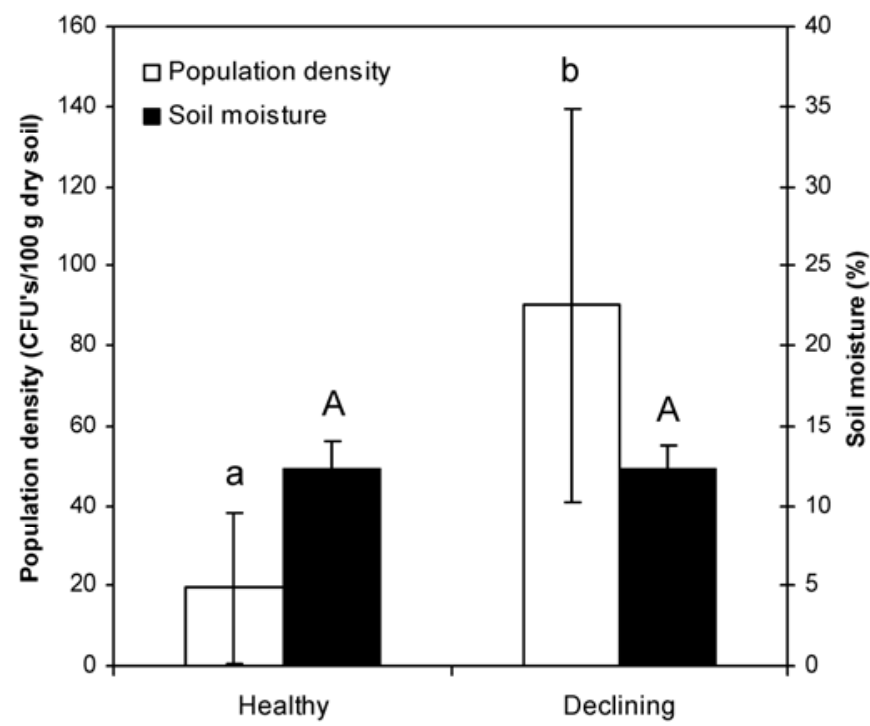

B

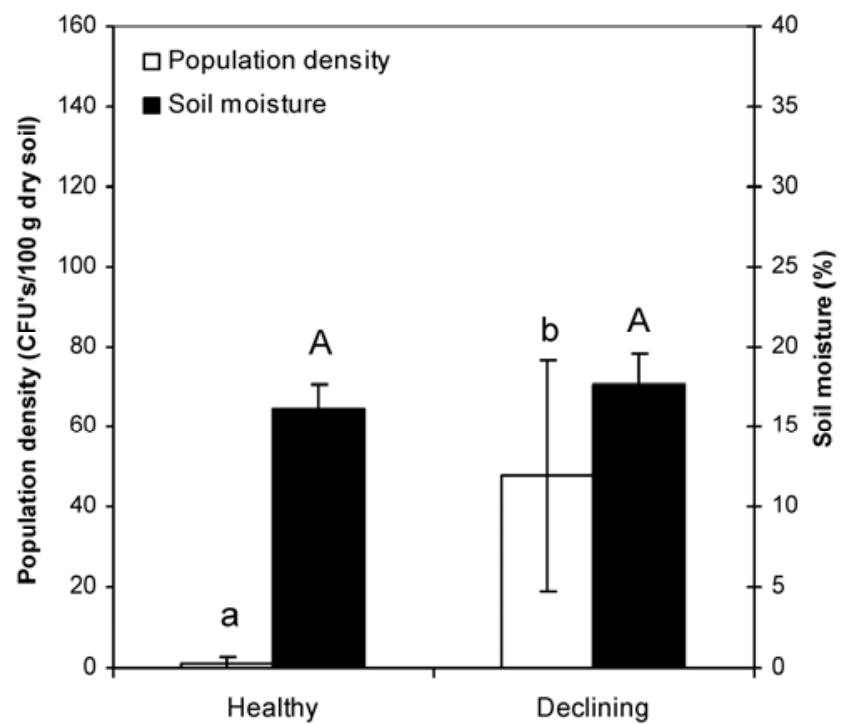

Fig. 1. Mean soil population densities (CFU per $100 \mathrm{~g}$ of dry soil \pm Standard error) of Phytophthora cinnamomi and soil moisture levels for four study sites at Scioto Trail State Forest in southern Ohio over all sampling dates in A, July-October 2008 and B, June-August 2009. Lowercase letters show differences between healthy and declining stands in P. cinnamomi population densities within sampling years while uppercase letters indicate differences in soil moisture. 
crosis than uninoculated controls. Institution of periodic flooding exacerbated root damage, resulting in significantly lower root dry mass in inoculated trees, and increased inoculum and root damage in uninoculated native soils.

Population densities of $P$. cinnamomi were highly variable within sites, and the pathogen was often isolated from a single slope position but not the others. Population densities also varied between sites with the same decline status within a sampling date, which suggests a patchy, heterogeneous distribution of the pathogen at both the site and landscape levels. Additionally, the lack of propagule patterning along slopes within sites did not reflect an influence of topography or topographically driven soil moisture differences at the site level. Therefore, our data cannot explain patterns in mortality observed within sites, with lower-slope trees experiencing heaviest decline. This result was somewhat surprising, given that Balci et al. (2) isolated P. cinnamomi with soil-baiting techniques more frequently from wetter areas (determined using integrated moisture index, a GIS-derived estimation of soil moisture accounting for soil water-holding capacity and several landscape characteristics; 15) at Scioto Trail. It is possible that our limited sampling strategy did not provide sufficient information on population dynamics, or that differences in moisture levels within sites were simply not large enough to produce detectable effects on population levels. This is consistent with a similar study where decline appeared to be more severe in valleys but slope position did not have a significant effect on isolation frequencies of $P$. cinnamomi from tree roots or soil in a large number of declining cork oak stands surveyed throughout Portugal (23).

Annual moisture averages were nearly identical in healthy and declining sites, suggesting that it is not variation in soil moisture levels between sites that is driving the population density differences seen in our study. It is possible that our method of sampling soil moisture (instantaneous volumetric measurement) did not capture subtle differences in drainage patterns or soil structure that would influence waterholding capacity at longer time scales. Additionally, instantaneous values cannot capture effects of episodic events (such as flooding) on population levels. The higher B horizon clay content in the sites with the greatest decline relative to the healthiest sites, as well as the finer textures observed in declining study sites (which also contained higher $P$. cinnamomi levels), may indicate interplay of soil factors other than moisture. A study of oak decline in Central Europe concluded that soils with higher clay and silt content supported higher levels of Phytophthora spp. than sandier sites (17). Another study did not find a significant association between soil texture and $P$. cinnamomi distribution but recovered the pathogen in highest frequencies from sites with fine textures (23). It is also possible that conducive microenvironments or other soil properties (e.g., depth or organic matter content) may play roles in determining pathogen distribution and inoculum production at Scioto Trail. Additionally, availability of susceptible host material and host condition likely play a role in disease development, and may also be influenced by environmental variables such as soil moisture patterns, soil texture, and slope position. Higher moisture content, which was related to lower slope positions in all but one of our field sites, may inhibit root development in white oak due to anoxic conditions. Similarly, soils with high clay content may also inhibit root growth as a result of increased mechanical resistance, anoxia, or both. Especially given that we observed a positive relationship between clay content in the B horizon (the primary rooting horizon) and decline status, it is possible that a combination of soil and site factors predispose white oak trees to decline or attack by $P$. cinnamomi through inhibition of healthy root system development.

Soil moisture may not be an important driver of propagule distribution at the site
A

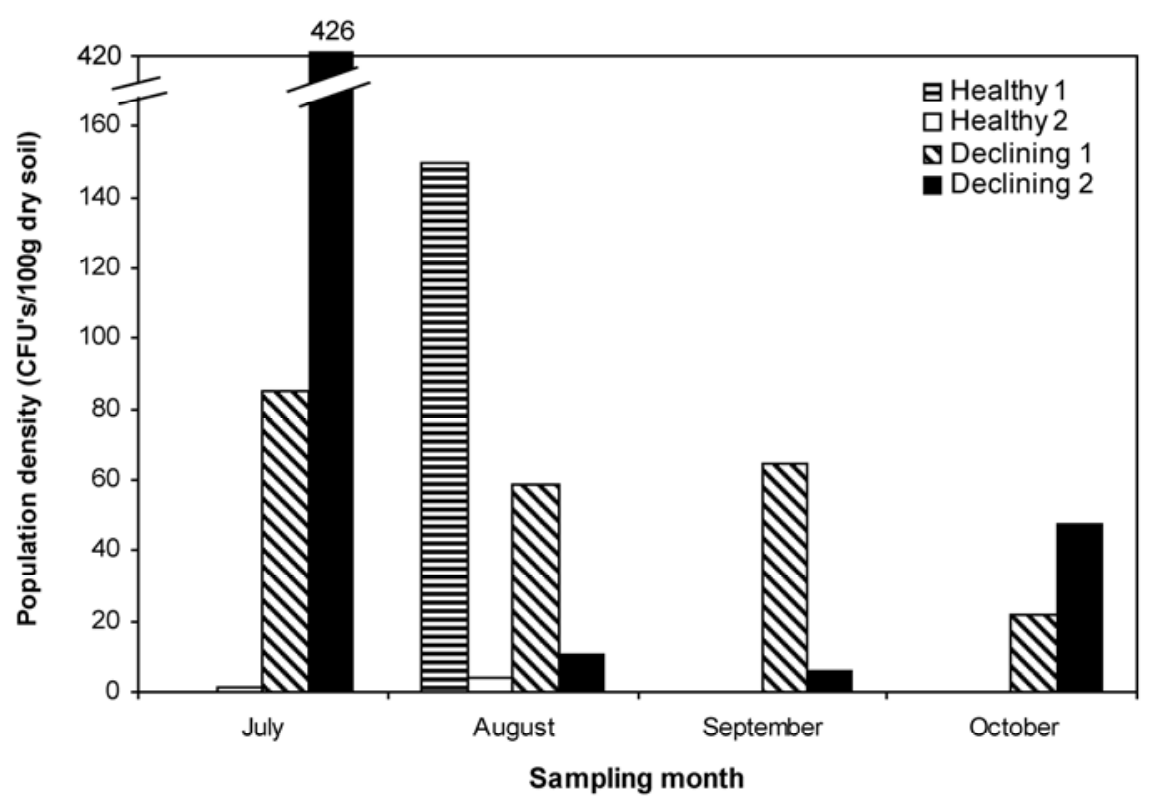

B

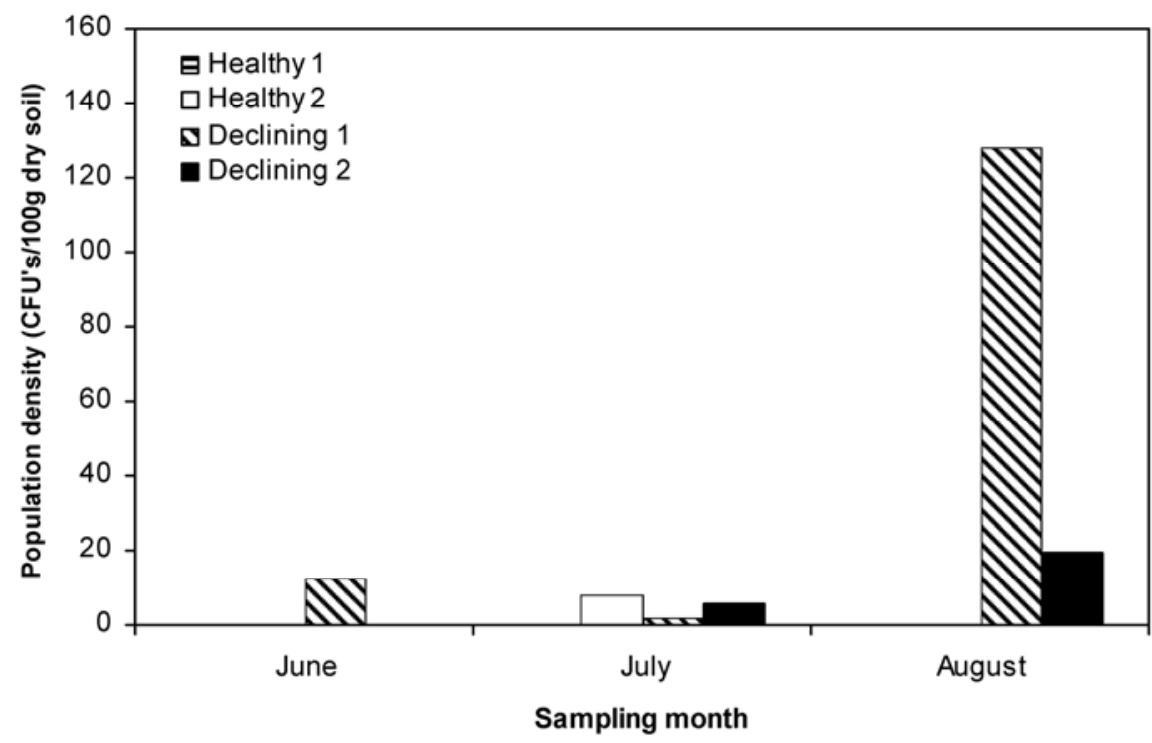

Fig. 2. Soil population densities (CFU per $100 \mathrm{~g}$ of dry soil) of Phytophthora cinnamomi in healthy and declining white oak stands at Scioto Trail State Forest, southern Ohio, for each month in A, JulyOctober 2008 and B, June-August 2009. Actual population density in site Declining 2 for July 2008 is indicated with a numeral above the corresponding bar. 
level but it may play an important role in determining seasonal pathogen abundance on a landscape scale. The observed exponential decline of total population densities with declining average moisture levels throughout the summer in 2008 suggests that longer periods of drying may be necessary to influence pathogen activity; however, the 2009 data does not support this hypothesis. The very low population levels at the June time point may be anomalous or may represent response to factors not examined in this study (e.g., low winter temperatures). However, there were only three sampling dates in 2009, limiting our ability to draw conclusions about overall patterns in population dynamics during that year.

The presence of higher population densities of $P$. cinnamomi in declining stands in both 2008 and 2009 provides circumstantial evidence that it contributes to white oak decline. Evidence from our field studies is strengthened by the observed relationship between elevated $P$. cinnamomi levels and increased incidence of root disease (evidenced by significantly more root necrosis and significantly lower root dry masses) in white oak inoculated in the greenhouse. Though inoculum densities produced by soil inoculations at rates of 2 and $5 \%$ soil volume are artificially high compared with those seen in field trials, it is interesting to note that naturally occurring inoculum in the potting mix from Declining 1 was capable of killing a tree on one occasion when periodic flooding was experimentally introduced, and root lesions were seen on other trees in the F0 group but not in the NF0 group. Heavy mortality after periodic flooding in yearold holm oak trees growing in soils naturally infested with $P$. cinnamomi was de- scribed in a previous study of an oak decline in Spain (12). Another study demonstrated heavy mortality of holm and cork oak seedlings grown in naturally infested soils from declining oak stands in Spain in the absence of flooding treatment (26). Though root disease of experimental trees was not assessed prior to inclusion in our study, seedling emergence, growth, and survival were high for trees planted in soil from the four field sites up until treatment, and did not differ between healthy and declining soils. Also, the lack of necrotic tap roots and failure to isolate $P$. cinnamomi from roots or soil in NF0 suggest that basal inoculum levels in native soils are not high enough to incite disease or mortality in greenhouse-grown white oak trees when adequate soil drainage is provided.

The mean inoculum density seen in F0 soils $(391 \pm 237 \mathrm{CFU}$ per $100 \mathrm{~g}$ of dry soil) was within the range of densities recovered from declining field sites during 2008 (up to approximately 430 CFU per $100 \mathrm{~g}$ of dry soil). P. cinnamomi inoculum and root damage were not detectable in NF0 soils but were detectable in F0 soils (though levels were not significantly higher), suggesting that periodic waterlogging due to rain events in certain areas of the forest may play a role in driving up preexisting inoculum levels enough to cause disease in the field.

Our field surveys did not attempt to isolate $P$. cinnamomi from tree roots. However, Balci et al. (2) isolated P. cinnamomi at relatively low frequencies ( 3 isolations from 10 extensively sampled trees) from necrotic root tissue of declining oak trees at Scioto Trail but not from the 10 healthy oak trees sampled. P. cinnamomi is notoriously difficult to recover from infected roots in the field and fresh lesions are typically required for successful isolation $(5,28)$. Studies on European oak decline systems have shown that root isolation frequencies vary widely between declining sites and can be very high in some cases $(12,23)$. However, there is evidence that root isolation frequencies depend heavily on soil characteristics and predominating tree species in the stand, and may be particularly low in dry conditions $(5,6)$.

In addition to isolation of $P$. cinnamomi from necrotic roots of declining white oak trees at Scioto Trail, Balci et al. (2) showed that individual declining trees have seven times fewer fine roots (by length) than healthy trees. The study also found that $P$. cinnamomi population levels in the rhizospheres of declining oak trees $(n=$ $30)$ were significantly higher than in soil around healthy oak trees $(n=15)$. The findings of Balci et al. (2), taken together with the results of our study, including the higher population levels of $P$. cinnamomi recovered from declining sites over 2 years of sampling, the higher levels of root necrosis and mass loss in inoculated white oak trees in the greenhouse, and the enhancement of root disease with periodic flooding, provide strong circumstantial evidence that $P$. cinnamomi may play a role in white oak decline in southern Ohio.

$P$. cinnamomi is a widely recognized invasive pathogen throughout the world. In certain areas where it has been introduced to native ecosystems, such as the jarrah forests of Australia $(13,24,34)$ or the chestnut and pine forests of the southern United States $(7,9)$, this pathogen has caused dramatic, severe decline and mortality. However, it is possible that this pathogen is also capable of a more subtle role in forest ecology. There is no informa-
A

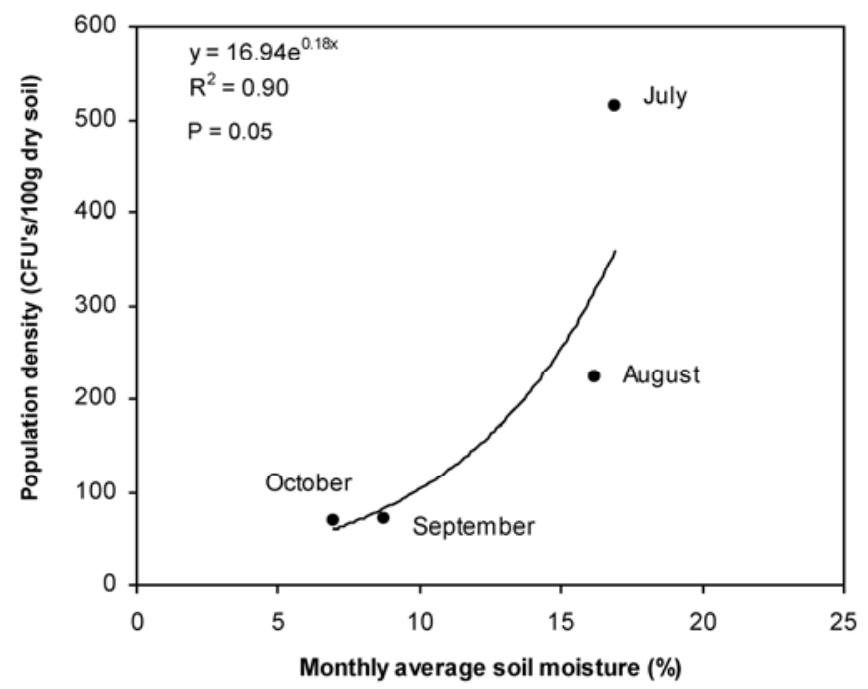

B

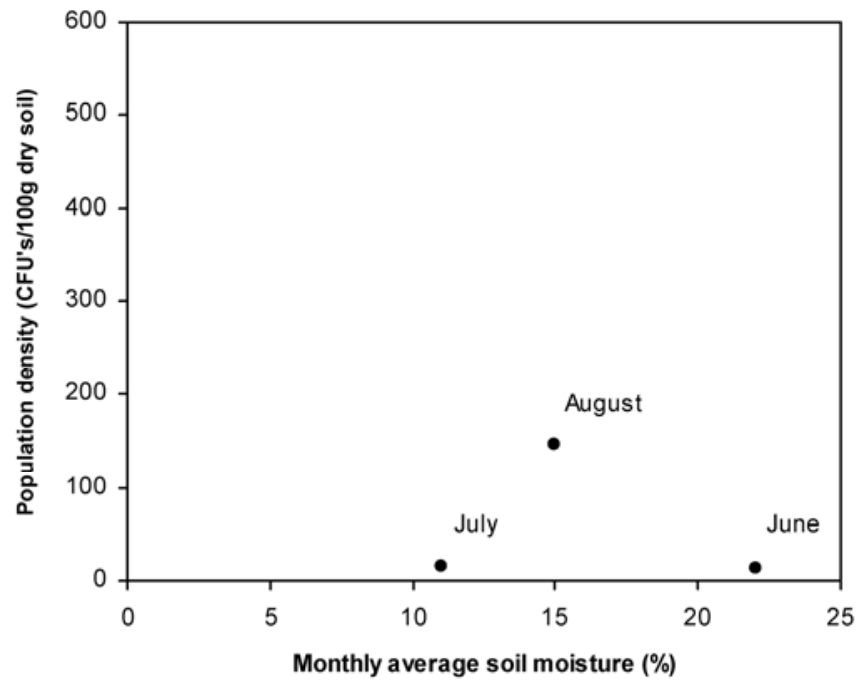

Fig. 3. Relationship between monthly average soil moisture levels and total monthly population densities (CFU per $100 \mathrm{~g}$ of dry soil) of Phytophthora cinnamomi at Scioto Trail State Forest, southern Ohio, in A, 2008 and B, 2009. Data points represent total population densities from four study plots (two healthy and two declining white oak stands) and monthly average soil moistures. Volumetric soil moistures were taken twice each month, at 2 weeks prior to soil sampling and on the day of soil sampling. 
tion concerning timing of $P$. cinnamomi's introduction or rate of spread in southern Ohio; however, native chestnuts and chinquapins were observed dying of root rot (later attributed to $P$. cinnamomi) in northern Tennessee in the nineteenth century, and symptomatic Castanea spp. were observed along the Appalachian corridor as

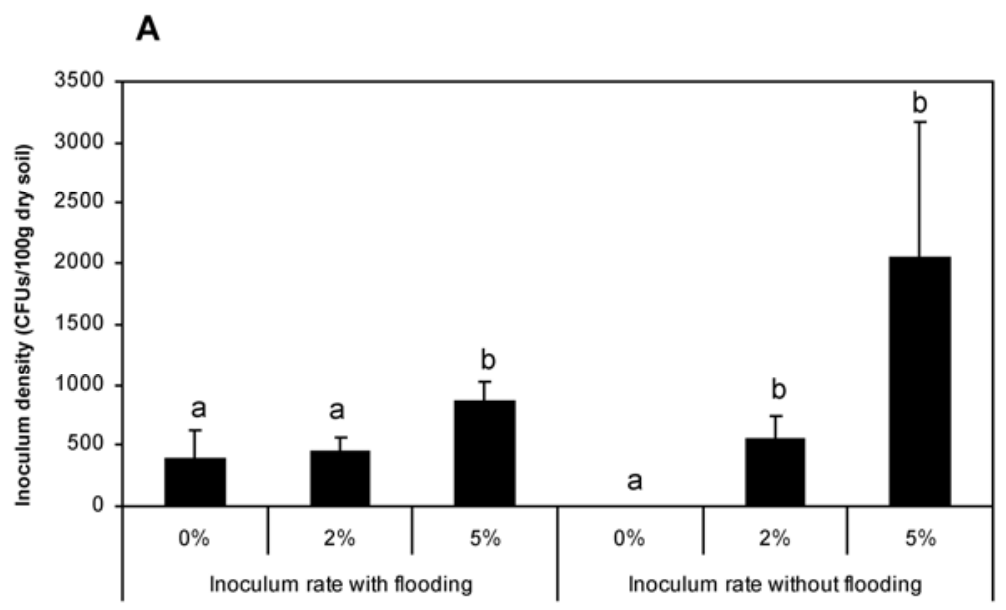

Treatment combination

$$
\text { B }
$$

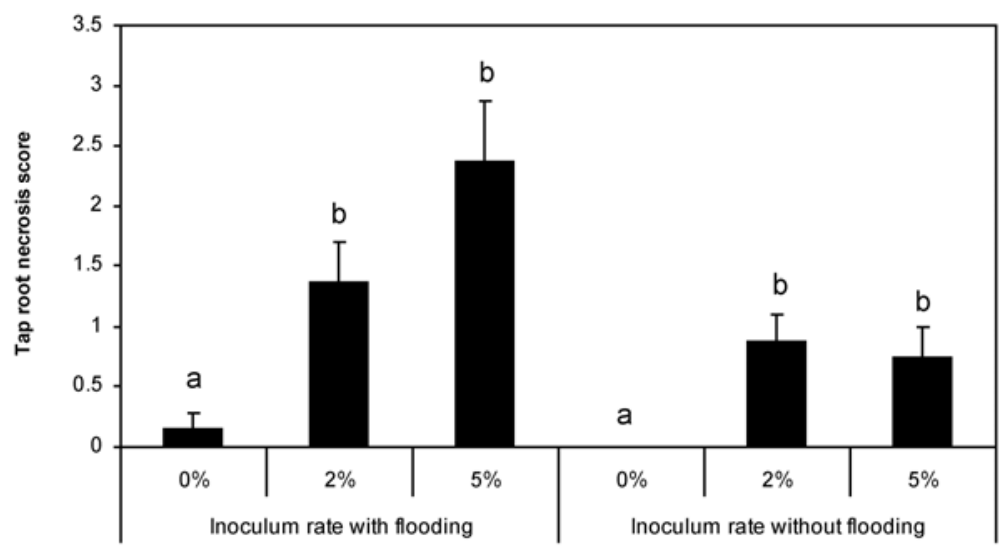

Treatment combination

C

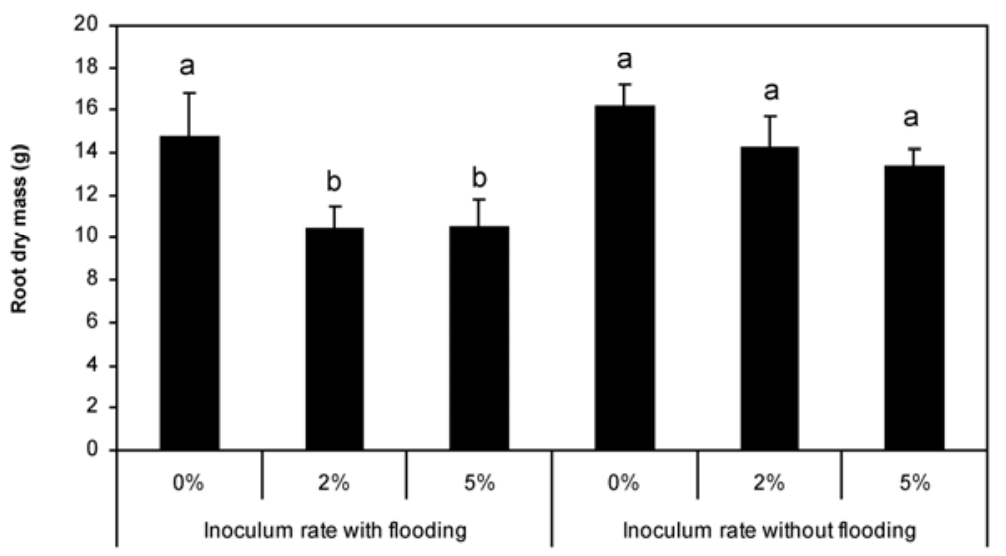

Treatment combination

Fig. 4. Results from Phytophthora cinnamomi soil inoculum dose-response greenhouse assay conducted using potted, 1-year-old white oak trees in summer 2009. Seedlings were subjected to a flooding or no-flooding moisture regime with three soil inoculum levels $(0,2$, and $5 \%$ of total soil volume) for a total of six treatment combinations $(n=8$ seedlings/treatment). Response variables measured were A, final soil inoculum density (mean \pm standard error) of $P$. cinnamomi; $\mathbf{B}$, tap root necrosis score (mean \pm standard error); and $\mathbf{C}$, root dry mass (mean \pm standard error). A necrosis score of $0=$ no damage and $1=$ up to $25,2=25-50,3=50-75$, and $4=75-100 \%$ necrotic. Letters indicate significant differences from the control group (no flooding, $0 \%$ inoculum). far north as Maryland by 1944 (7). If $P$. cinnamomi has been a component of southern Ohio soils for a long time, it is conceivable that we are currently observing effects of many years of root rot. Stress by environmental factors may create a tipping point in tree physiology that favors expression of the negative effects of a latent pathogen that is not a natural ecological component, resulting in decline and mortality. It is also possible that the observed decline is ontological in nature, and related to aging of the white oak stands. Though different size classes are present at Scioto Trail, white oak trees are largely of the same age (between 90 and 150 years old), with recruits rarely moving beyond the seedling stage (14). Relative to younger oak trees, studies have shown that older oak trees have a reduced ability to regenerate roots after damage (31) and form new roots in better soils $(3,31)$. It is possible that rates of root loss tolerated by younger white oak trees at Scioto Trail have become unsustainable as they have aged, inciting the observed decline. A similar hypothesis has been put forth regarding declines of $Q$. robur and $Q$. patraea likely incited by $P$. quercina in Europe (17). However, $P$. cinnamomi may be a more recent immigrant to Ohio forests, or environmental conditions may now be conducive to disease development. The latter hypothesis is intriguing, considering that the northerly limit to $P$. cinnamomi's current range in the eastern United States appears to be around $40^{\circ} \mathrm{N}$, which falls only about $100 \mathrm{~km}$ north of Scioto Trail (1). Therefore, it is possible that its movement into or survival and reproduction in these forests have been facilitated by warming winter temperatures. Models have predicted a similar northerly range expansion in $P$. cinnamomi populations in Europe $(4,5,8)$ under projected higher minimum winter temperatures and longer windows of warmer temperatures conducive to sporulation and root infection (18).

Phytophthora pathogens have proven extremely difficult to manage in forest settings; thus, immediate management recommendations may not extend beyond careful sanitation and mitigation of human-facilitated spread. Clearly, more indepth research into the environmental drivers of this hypothesized epidemic, as well as the value of a range of possible management options, is warranted in the future.

\section{ACKNOWLEDGMENTS}

Funding for this research was provided by an Ohio Agricultural Research and Development Center grant to A. M. Nagle and state funds appropriated to the Department of Plant Pathology, The Ohio State University. We thank Y. Balci for assistance with experimental design and procedures; T. Fox for extensive assistance with fieldwork and soil texture analyses; and C. Rico, S. Quinn, C. Baker, A. Hoffstetter, R. Snyder, and W. Hilinski for their assistance in field work and laboratory assays. 


\section{LITERATURE CITED}

1. Balci, Y., Balci, S., Eggers, J., MacDonald, W. L., Juzwik, J., Long, R. P., and Gottschalk, K. W. 2007. Phytophthora spp. associated with forest soils in eastern and north-central US oak ecosystems. Plant Dis. 91:705-710.

2. Balci, Y., Long, R. P., Balser, D., and MacDonald, W. L. 2009. Involvement of Phytophthora species in white oak $(Q$. alba) decline in southern Ohio. For. Pathol. Published online: Sep 14 2009, DOI: 10.1111/j.14390329.2009.00617.x.

3. Becker, M., and Levy, G. 1986. Compared radial growth of adult oaks (Quercus robur $\mathrm{L}$ and Quercus petraea (Matt) Liebl) on acid waterlogged soil-influence of drainage. Acta. Oecol. Oecol. Plant. 7:121-143.

4. Bergot, M., Cloppet, E., Perarnaud, V., Deque, M., Marcais, B., and Desprez-Loustau, M. L. 2004. Simulation of potential range expansion of oak disease caused by Phytophthora cinnamomi under climate change. Global Change Biol. 10:1539-1552.

5. Brasier, C. M. 1996. Phytophthora cinnamomi and oak decline in southern Europe. Environmental constraints including climate change. Ann. Sci. For. 53:347-358.

6. Brasier, C. M., Robredo, F., and Ferraz, J. F. P. 1993. Evidence for Phytophthora cinnamomi involvement in Iberian oak decline. Plant Pathol. 42:140-145.

7. Crandall, B. S., Gravatt, G. F., and Ryan, M. M. 1945. Root disease of Castanea species and some coniferous and broadleaf nursery stocks, caused by Phytophthora cinnamomi. Phytopathology 35:162-180.

8. Desprez-Loustau, M. L., Robin, C., Reynaud, G., Deque, M., Badeau, V., Piou, D., Husson, C., and Marcais, B. 2007. Simulating the effects of a climate-change scenario on the geographical range and activity of forestpathogenic fungi. Can. J. Plant. Pathol. 29:101-120.

9. Erwin, D. C., and Ribeiro, O. K. 1996. Phytophthora Diseases Worldwide. The American Phytopathological Society, St. Paul, MN.

10. Farmer, R. E. 1979. Dormancy and root growth capacity of white and sawtooth oaks. For. Sci. 25:491-494.

11. Ferguson, A. J., and Jeffers, S. N. 1999. Detecting multiple species of Phytophthora in container mixes from ornamental crop nurseries. Plant Dis. 83:1129-1136.

12. Gallego, F. J., de Algaba, A. P., and Fernandez-
Escobar, R. 1999. Etiology of oak decline in Spain. Eur. J. For. Pathol. 29:17-27.

13. Hansen, E. M. 2008. Alien forest pathogens: Phytophthora species are changing world forests. Boreal Environ. Res. 13:33-41.

14. Hutchinson, T. F., Long, R. P., Ford, R. D., and Sutherland, E. K. 2008. Fire history and the establishment of oaks and maples in secondgrowth forests. Can. J. For. Res. 38:1184-1198.

15. Iverson, L. R., Dale, M. E., Scott, C. T., and Prasad, A. 1997. A GIS-derived integrated moisture index to predict forest composition and productivity of Ohio forests (USA). Landsc. Ecol. 12:331-348.

16. Jonsson, U. 2006. A conceptual model for the development of Phytophthora disease in Quercus robur. New Phytol. 171:55-68.

17. Jung, T., Blaschke, H., and Osswald, W. 2000. Involvement of soilborne Phytophthora species in Central European oak decline and the effect of site factors on the disease. Plant Pathol. 49:706-718.

18. Kliejunas, J. T., Geils, B. W., Glaeser, J. M., Goheen, E. M., Hennon, P., Kim, M., Kope, H., Stone, J., Sturrock, R., and Frankel, S. J. 2009. Review of literature on climate change and forest diseases of western North America. Gen. Tech. Rep. PSW-GTR-225. U. S. Dep. Agric. For. Serv. Pac. Southwest Res. Stn. Albany, CA.

19. Kong, P., Hong, C. X., and Richardson, P. A. 2003. Rapid detection of Phytophthora cinnamomi using PCR with primers derived from the Lpv putative storage protein genes. Plant Pathol. 52:681-693.

20. Letson, S. P., Sabula, A., and Romig, R. L. 2006. OHIO: The many sides of the forest economy. Ohio Forestry Association, Inc. Online publication. Retrieved 23 March 2010. http://www.dnr.state.oh.us/portals/18/publicati ons/pdf/OFA_manysidesreport.pdf.

21. Manion, P. D. 1991. Tree Disease Concepts. Prentice Hall, Englewood Cliffs, N.J.

22. McCarthy, B. C., and Keiffer., C. H. 2004. Hardwood seed production in an old-growth mixed mesophytic forest in southeastern Ohio. Pages 527-529 in: Proc. 14th Cent. Hardwood For. Conf. D. A. Yaussy, D. M. Hix, R. P. Long, and P. C. Goebel, eds. U. S. Dep. Agric. For. Serv. Northeastern Res. Stn. Wooster, OH.

23. Moreira, A. C., and Martins, J. M. S. 2005. Influence of site factors on the impact of Phytophthora cinnamomi in cork oak stands in Portugal. For. Pathol. 35:145-162.
24. Newhook, F. J., and Podger, F. D. 1972. Role of Phytophthora cinnamomi in Australian and New Zealand forests. Annu. Rev. Phytopathol. 10:299-326.

25. Robin, C., Capron, G., and Desprez-Loustau, M. L. 2001. Root infection by Phytophthora cinnamomi in seedlings of three oak species. Plant Pathol. 50:708-716.

26. Rodriguez-Molina, M. C., Torres-Vila, L. M., Blanco-Santos, A., Nunez, E. J. P., and TorresAlvarez, E. 2002. Viability of holm and cork oak seedlings from acorns sown in soils naturally infected with Phytophthora cinnamomi. For. Pathol. 32:365-372.

27. Roiger, D. J., and Jeffers, S. N. 1991. Evaluation of Trichoderma spp. for biological control of Phytophthora crown and root-rot of apple seedlings. Phytopathology 81:910-917.

28. Sanchez, M. E., Caetano, P., Ferraz, J., and Trapero, A. 2002. Phytophthora disease of Quercus ilex in south-western Spain. For. Pathol. 32:5-18.

29. Shah, D. A., and Madden, L. V. 2004. Nonparametric analysis of ordinal data in designed factorial experiments. Phytopathology 94:3343.

30. Sheldrick, B. H., and Wang, C. 1993. Particle size distribution. Pages 499-511 in: Soil Sampling and Methods of Analysis. M. R. Carter, ed. CRC Press, Boca Raton, FL.

31. Thomas, F. M., and Hartmann, G. 1998. Tree rooting patterns and soil water relations of healthy and damaged stands of mature oak (Quercus robur L and Quercus petraea [Matt] Liebl). Plant Soil 203:145-158.

32. Vettraino, A. M., Belisario, A., Maccaroni, M., and Vannini, A. 2003. Evaluation of root damage to English walnut caused by five Phytophthora species. Plant Pathol. 52:491-495.

33. Wargo, P. M., Houston, D. R., and LaMadeleine., L. A. 1983. Oak Decline. Forest Insect and Disease Leaflet 165. U. S. Dep. Agric. For Serv. Online publication. Retrieved 23 March 2010. http://www.na.fs.fed.us/spfo/pubs/fidls/ oakdecline/oakdecline.htm.

34. Weste, G., and Marks, G. C. 1987. The biology of Phytophthora cinnamomi in Australasian forests. Annu. Rev. Phytopathol. 25:207-229.

35. Widmann, R., Balser, D., Barnett, C., Butler, B. J., Griffith, D. M., Lister, T. W., Moser, W. K., Perry, C. H., Riemann, R., and Woodall, C. W. 2009. Ohio forests: 2006. Resource Bulletin NRS-36. U.S. Dep. Agric. For. Serv. Northern Res. Stn. Newtown Square, PA. 